\title{
Evidence for focused magmatic accretion at segment centers from lateral dike injections captured beneath the Red Sea rift in Afar
}

\author{
Derek Keir ${ }^{1,2}$, Ian J. Hamling ${ }^{1}$, Atalay Ayele ${ }^{3}$, Eric Calais ${ }^{4}$, Cindy Ebinger ${ }^{5}$, Tim J. Wright ${ }^{1}$, Eric Jacques ${ }^{6}$, Kassim Mohamed ${ }^{7}$, \\ James O.S. Hammond ${ }^{8}$, Manahloh Belachew ${ }^{5}$, Elizabeth Baker ${ }^{2}$, Julie V. Rowland ${ }^{9}$, Elias Lewi ${ }^{3}$, Laura Bennati ${ }^{4}$ \\ 'School of Earth and Environment, University of Leeds, Leeds LS2 9JT, UK \\ 2Department of Earth Sciences, Royal Holloway University of London, Egham TW20 OEX, UK \\ ${ }^{3}$ Institute of Geophysics, Space Science and Astronomy, Addis Ababa University, Addis Ababa, PO Box 1176, Ethiopia \\ ${ }^{4}$ Department of Earth and Atmospheric Sciences, Purdue University, West Lafayette, Indiana 47907, USA \\ ${ }^{5}$ Department of Earth and Environmental Sciences, University of Rochester, Rochester, New York 14618, USA \\ ${ }^{6}$ Institut de Physique du Globe de Paris, 4, Place Jussieu, 75252 Paris, France \\ 'Observatoire de Géophysique d'Arta, Arta, Djibouti \\ ${ }^{8}$ Department of Earth Sciences, University of Bristol, Bristol BS8 1RJ, UK \\ ${ }^{9}$ School of Geography, Geology and Environmental Science, University of Auckland, New Zealand
}

\section{ABSTRACT}

Continental breakup occurs through repeated episodes of mechanical stretching and dike injection within discrete, narrow rift segments. However, the time and length scales of the dike intrusions, along with the source regions of melt within continental and oceanic rifts, are poorly constrained. We present measurements of spatial and temporal variability in deformation from the currently active 60-km-long Dabbahu segment of the Red Sea rift in Afar, using satellite radar, global positioning system, and seismicity data sets, that capture emplacement of two 10-km-long, 1-2-m-wide dike intrusions in June and July 2006. Our observations show that the majority of strain is accommodated by dikes that propagate laterally over $\sim 4-5 \mathrm{~h}$ time scales along the rift axis and are sourced from a reservoir in the middle to lower crust, or upper mantle, beneath the center of the rift segment. New intrusions during the ongoing rifting episode in Afar show that the injection of lateral dikes fed from magma reservoirs beneath rift segment centers is a key component in creating and maintaining regular along-axis rift segmentation during the final stages of continental breakup. Our observations also provide evidence that the focused magmatic accretion at segment centers observed in slow-spreading mid-ocean ridges occurs prior to the onset of seafloor spreading.

\section{INTRODUCTION}

Dike intrusion is a ubiquitous process achieving seafloor spreading in oceanic rifts, and accommodating the majority of strain in some continental rift zones (e.g., Delaney et al., 1998; Buck, 2004). However, length and time scales of the extensional process in magmatic rifts are poorly understood because the earthquake and surface deformation induced by magma injection is so infrequently recorded by seismic and geodetic monitoring equipment. We rely, therefore, on rare large dike intrusions to quantify the associated strain patterns and magma sources (e.g., Björnsson et al., 1977; Abdallah et al., 1979; Tolstoy et al., 2006).

In September 2005, a 60-km-long nascent seafloor-spreading segment of the Red Sea rift in Afar (Ethiopia) ruptured with intrusion of a dike that marked the beginning of a rifting episode (Wright et al., 2006; Ayele et al., 2007) (Fig. 1). We use a unique combination of seismic, geodetic, and field data sets collected during rapid response monitoring efforts to identify and model new discrete dike intrusions intruding beneath the rift axis in June and July 2006. For the first time, we have captured and quantified the process of bidirectional, lateral dike injection sourced from a magma reservoir beneath the center of a rift segment prior to the onset of seafloor spreading.

\section{RIFT SEGMENTS IN AFAR}

Rifting between Arabia, Somalia, and Nubia during the past $\sim 30$ m.y. produced the $\sim 300-\mathrm{km}$ wide Afar depression at the triple junction between the Red Sea, Gulf of Aden, and East African rifts, formed within the Paleogene flood basalt province associated with the Afar mantle plume (Fig. 1) (e.g., Hofmann et al., 1997; Montelli et al., 2004). Since ca. 3 Ma, faulting and volcanism in the subaerial Red Sea rift within Afar have localized to $\sim 15-\mathrm{km}$-wide, $\sim 60-\mathrm{km}$ long faulted volcanic ranges with aligned chains of basaltic cones and fissural flows. These rift segments (e.g., Dabbahu segment) are similar in size, morphology, structure, and spacing to the second-order non-transform segments of a slow-spreading mid-ocean ridge (Hayward and Ebinger, 1996; Manighetti et al., 1998). Geodetic data show that current Nubia-Arabia extensional velocity is $\sim 16 \mathrm{~mm} \mathrm{yr}^{-1}$ (Vigny et al., 2006), resulting in continued deformation of already highly extended and intruded $~ 18-22-\mathrm{km}$-thick crust (Makris and Ginzburg, 1987).

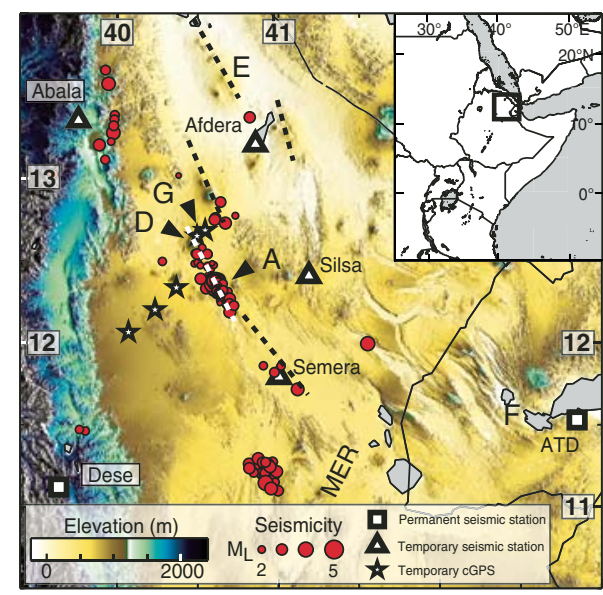

Figure 1. Earthquakes during April-August 2006 recorded on temporary broadband seismic stations (triangles) and permanent short period stations (squares). Seismic stations are in named towns (ATD-Arta, Djibouti) and stars denote continuous global positioning system (cGPS) stations. Major volcanic centers: A-Ado'Ale Volcanic Complex, D-Dabbahu, E-Erta'Ale, F-Fielle, G-Gabho. Dashed white line shows axis of Dabbahu segment; dashed black lines show axes of other subaerial Red Sea rift segments. Top right inset shows location of Afar.

During September 2005, $\sim 2.5 \mathrm{~km}^{3}$ of magma was injected as near vertical dikes into the upper $\sim 10 \mathrm{~km}$ of crust beneath the entire $\sim 60$-km-length of the Dabbahu segment, and caused as much as $\sim 8 \mathrm{~m}$ of horizontal opening. Magma accommodated $\sim 90 \%$ of the total geodetic moment, implying a relatively minor contribution by induced normal faulting near the surface (Wright et al., 2006; Rowland et al., 2007). Simple elastic models of deformation measured using interferometric synthetic aperture radar (InSAR) show that deflation of shallow (5 km deep) magma chambers beneath Dabbahu and Gab'ho volcanoes at the northern end of the segment accounts for only $20 \%$ of total dike volume. The volume imbalance 
between source and dike is explained by either expansion of remaining magma in the chamber from gas exsolving caused by pressure drop, or the presence of an additional source deeper beneath the rift (Wright et al., 2006). However, neither seismicity nor geodetic data from the September 2005 dike can resolve the position of important additional magma sources, or temporal and directional characteristics of dike emplacement. Only in the few months following September 2005 did a broad $\sim 10 \mathrm{~cm}$ uplift of the Ado'Ale Volcanic Complex near the center of the Dabbahu segment provide some evidence of a middle to lower crustal magma reservoir (Calais et al., 2006; Ebinger et al., 2008).

\section{DEFORMATION BENEATH RIFT SEGMENT CENTER}

Seismicity patterns recorded on temporary and permanent stations in Ethiopia and Djibouti provide a continuous record of deformation in Afar (Fig. 1). Details of data sets and methods are supplied in the GSA Data Repository ${ }^{1}$ and all quoted times are in Greenwich Mean Time (GMT). Between April and August 2006, 182 earthquakes $\left(M_{L}\right.$ 1.4-4.7) were located in Afar (Fig. 1). The majority of seismicity is along the axis of the Dabbahu segment and occurred within one of two major earthquake swarms on 17-22 June and 25-26 July 2006 that ruptured the same 2-3-kmwide zone as in September 2005.

We use radar data acquired by the European Space Agency's Envisat satellite to form ascending and descending interferograms that record the surface deformation in Afar, providing a framework for seismicity and continuous global positioning system (cGPS) studies outlined below. Interferograms spanning seismic swarms show intense deformation at the Dabbahu segment center (Fig. 2). Simple elastic modeling of combined InSAR and cGPS data shows that deformation is consistent with tensile dislocation (dike) and a minor amount of induced fault slip near the surface (Fig. 2). The first modeled dike is $\sim 10 \mathrm{~km}$ long, intrudes $0-10 \mathrm{~km}$ depth range, has an opening that varies from near zero at the dike tips to a maximum of $2.2 \pm 0.1 \mathrm{~m}$, estimated volume of $0.12 \pm 0.02 \mathrm{~km}^{3}$, and released $3.7 \times 10^{18} \mathrm{Nm}$ geodetic moment. The second modeled dike is $\sim 9 \mathrm{~km}$ long, intrudes $0-5 \mathrm{~km}$ depth range, has a maximum opening of $1.1 \pm 0.1 \mathrm{~m}$, estimated volume of $0.07 \pm 0.02 \mathrm{~km}^{3}$, and released $2.2 \times 10^{18} \mathrm{Nm}$ geodetic moment. Neither dike intrusions are accompanied by subsidence of Dabbahu and Gab'ho volcanoes, nor do elastic models require deflation of a Mogi source beneath the Ado'Ale Volcanic Complex.

${ }^{1}$ GSA Data Repository item 2009014, methods and topographic map of the Ado'Ale Volcanic Complex, is available online at www.geosociety.org/pubs/ ft2009.htm, or on request from editing@geosociety. org or Documents Secretary, GSA, P.O. Box 9140, Boulder, CO 80301, USA.
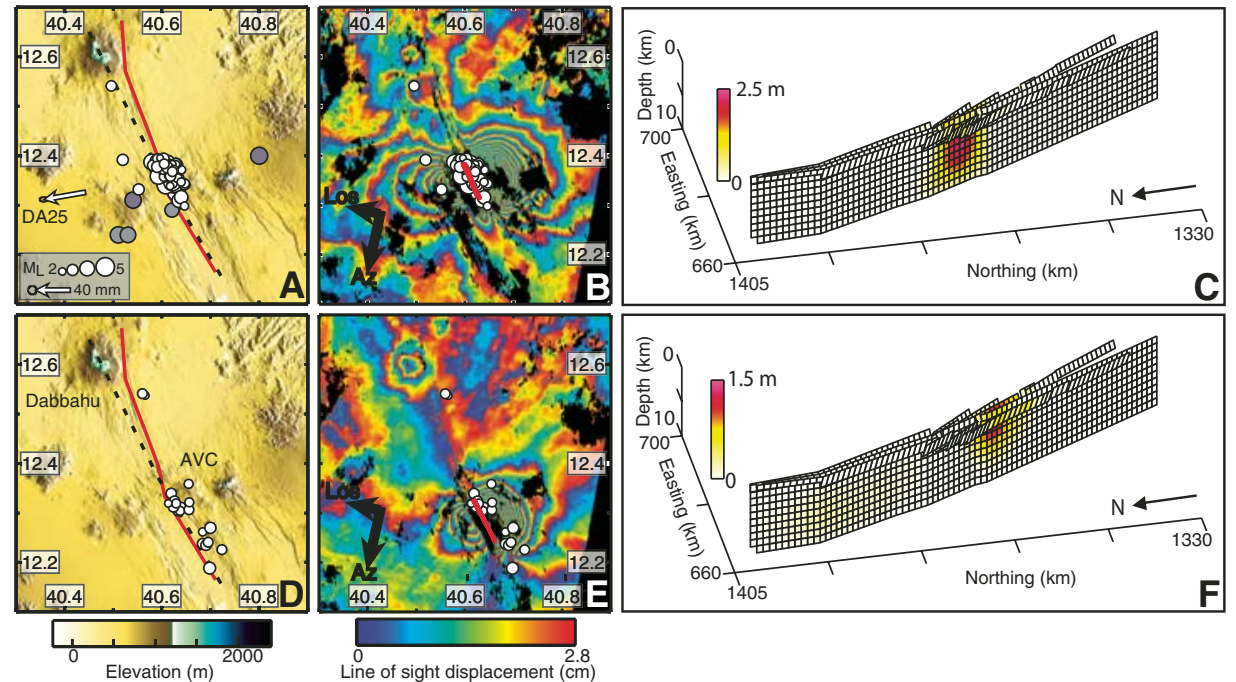

Figure 2. A: Seismicity during 20 May-24 June 2006 on topography. B: Seismicity during 20 May-24 June 2006 on descending interferogram. White circles are earthquake locations as recorded by the local network and gray circles are five earthquakes reported by National Earthquake Information Center on 17 June. Dashed black line is position of along-axis topographic profiles in Figure 3. Segment-long red line shows position of modeled September 2005 dike. White arrow shows horizontal motion at continuous global positioning system station DA25. Error ellipse shows $95 \%$ confidence interval. Solid red line on interferograms shows position of modeled dike shown in C. Az-azimuth; Los-line of sight. C: Elastic model of June 2006 dike opening. D, E: As in A and B, except seismicity and descending interferogram span 24 June-29 July 2006. AVC-Ado'Ale Volcanic Complex F: Elastic model of July 2006 dike opening.

Seismicity and cGPS were used to detect the timing and location of dike intrusions. On 17 June 2006, the National Earthquake Information Center (NEIC) reported five earthquakes of $\mathrm{m}_{\mathrm{b}}$ 3.9-4.6 scattered across an 20-km-wide zone near the Ado'Ale Volcanic Complex (Fig. 2). However, data from nearby stations significantly improve the record of seismicity. During 17-22 June, 73 earthquakes of $\mathrm{M}_{\mathrm{L}}$ 2.5-4.7 were located within an $\sim 10-\mathrm{km}-$ long, $\sim 5-\mathrm{km}$ wide, N-NW-striking cluster on the eastern side of the rift axis where it cuts the northern flank of the Ado'Ale Volcanic Complex, coincident with spatial extent of surface deformation recorded by InSAR (Fig. 2).

The first recorded earthquake occurred at 12:39 GMT near the southern end of the swarm (Fig. 3). Activity remained low until 13:16, and during the following $4 \mathrm{~h}$ a swarm of seismicity progressively migrated northward to a total distance of $\sim 10 \mathrm{~km}$ at an average velocity of $\sim 0.5 \mathrm{~m} / \mathrm{s}$. However, close inspection of data shows that between 13:16 and 14:33 seismicity migrated $\sim 6 \mathrm{~km}$ at a velocity of as much as $\sim 1.5 \mathrm{~m} / \mathrm{s}$, after which the migration rate decayed. The largest magnitude earthquakes (and resulting majority of total $1.8 \times 10^{17} \mathrm{Nm}$ seismic moment) occurred during the $\sim 4$-h-long phase of swarm migration. From 17:30 17 June until 22 June, low-magnitude $\left(\mathrm{M}_{\mathrm{L}}<3.5\right)$ seismicity was scattered throughout the deforming zone. Earthquake depths cannot be reliably constrained from our seismic data recorded on few distant stations. However, depth-constrained rift axis seismicity from higher-resolution data shows an $\sim 8$-km-thick seismogenic layer (Ebinger et al., 2008).

On 17 June 2006, cGPS data from station DA25 located $25 \mathrm{~km}$ west of the Dabbahu segment showed $47 \mathrm{~mm}$ westward motion (Fig. 2). The spatial coincidence between locus of seismicity and modeled dike (Fig. 2), as well as temporal coincidence between rift opening and migrating seismicity (Fig. 3), suggests that the migrating swarm of larger magnitude seismicity is caused by inflation-induced tension near the tip of a propagating dike (e.g., Rubin and Gillard, 1998; Roman and Cashman, 2006).

Few earthquakes were recorded until 25-26 July, when $19 \mathrm{M}_{\mathrm{L}}$ 2-3 earthquakes were detected in an $\sim 15-\mathrm{km}$-long, N-NW-S-SEelongate cluster on the eastern side of the rift axis where it cuts the southern flank of the Ado'Ale Volcanic Complex (Fig. 2). Between 20:00 and 21:00 on 25 July, seismicity occurred near the northern end of the swarm, and during the following $6 \mathrm{~h}$ it migrated $15 \mathrm{~km}$ south at an average velocity of $\sim 0.75 \mathrm{~m} / \mathrm{s}$ (Fig. 3). However, within the first $1.5 \mathrm{~h}$ the swarm initially migrated as much as $6 \mathrm{~km}$ at $>\sim 1 \mathrm{~m} / \mathrm{s}$, after which the rate of migration decayed. Total seismic moment release is estimated as $1.6 \times 10^{15} \mathrm{Nm}$.

The satellite radar, cGPS, and seismicity data show that two discrete, rift-parallel dike injections occurred beneath the center of the Dabbahu segment. Dikes occurring on 17 June and 25 July 
Figure 3. A: East-west motion at continuous global positioning system station (cGPS) DA25 and along-axis position of earthquakes in the Dabbahu segment against time. Earthquakes are colored and scaled by magnitude, and error bars are measured errors in arrival times. Two horizontal lines correspond to inferred dike source. Data within dashed rectangles are enlarged for detail. Along-axis topographic profile displayed in Figure 2 is in right panel. B: Three days east-west motion at cGPS DA25. Shaded histograms are seismic moment release in $\mathbf{2 ~} \mathrm{h}$ intervals and show that rift opening is coincident with peak in seismicity. C: Along-axis position in seismicity, as in A, but over $\sim 1$ day, showing migration of seismic swarms away from Ado'Ale Volcanic Complex. Histograms show seismic moment release binned at hour intervals and plotted on log scale. GMT-Greenwich Mean Time.

intruded beneath the northern and southern flanks of the Ado'Ale Volcanic Complex, respectively, and propagated laterally in the crust from a single source positioned approximately beneath the center of the complex. Both dikes intruded over $\sim 4-5 \mathrm{~h}$ time scales, during which the amount and magnitude of seismicity peaked. Seismic moment release accounts for only $5 \%$ of $3.71 \times 10^{18} \mathrm{Nm}$ geodetic moment released on 17 June, and $<1 \%$ of $2.2 \times 10^{18} \mathrm{Nm}$ released on 25 July. Therefore, magma intrusion accounts for the vast majority of deformation during diking.

\section{DISCUSSION}

The spatial and temporal characteristics of magma intrusion in the Dabbahu segment share similarities with the 1975-1984 Krafla rifting episode in northern Iceland, during which $9 \mathrm{~m}$ of rift opening was achieved through 20 discrete basaltic intrusions and fissural eruptions (Buck et al., 2006). The complex pattern of lateral, bidirectional dike propagation from a single source observed in Krafla is closely mimicked in numerical models assuming that dike propagation is driven by the difference between background stress and magma pressure (Buck et al., 2006). In such a scheme, successive dikes are preferentially drawn from a central chamber toward regions with the lowest minimum compressive stress, reaching the surface once background stress is completely relieved by intrusion. Dikes injected beneath the Dabbahu segment in June and July 2006 did not reach the surface, ruling out direct observations of dike composition. However, the similarity in propagation velocities (1-2 m/s) between dikes in Afar and Krafla (Einarsson and Brandsdóttir,
1980) and observed fissural basaltic eruption during August 2007 in the Dabbahu segment strongly point to basaltic dikes (G. Yirgu, 2007, personal commun.).

The combination of cGPS and seismicity data from the Dabbahu rift constrains the timing of dike growth. The temporal correlation between rift opening and seismicity coupled with marked reduction in amount and magnitude of seismicity at the cessation of swarm migration indicate that dike widening stopped when the tip of the dike stopped opening (e.g., Roman and Cashman, 2006). However, due to the physical complexities of diking, it is not clear whether the observed progressive decay in velocity of dike propagation is primarily controlled by (1) a drop in magma pressure as the dikes grow, (2) along-rift gradients in tectonic stress, (3) decrease in driving pressure gradient as the dike size increases, or (4) resistance to flow from dike freezing (e.g., Lister and Kerr, 1991; Fialko and Rubin, 1998).

The combined data sets indicate that the dikes are sourced from the center of the Dabbahu segment, yet the subsidence expected from withdrawal of magma from a chamber is not observed in InSAR or cGPS data. Our geodetic data cannot constrain the depth of the magma source. The absence of subsidence at the surface is likely in part due to magma expansion in the chamber caused by gas exsolving as pressure falls during magma escape, and/or the lower stiffness of tensile fractures compared to a spherical magma chamber (Rivalta and Segall, 2008). However, dikes being fed from a lower or subcrustal source is supported by cGPS and InSAR data in the few months following Septem- ber 2005 that show a 15-km-wide zone beneath the Ado'Ale Volcanic Complex with $10 \mathrm{~cm}$ of uplift, consistent with an inflating Mogi source 10-15 km deep (Calais et al., 2006). In addition, geochemistry of recent basalts is consistent with typical mid-ocean ridge basalts contaminated by gabbroic cumulates near the base of the crust (Barrat et al., 2003), lending further support to the presence of a lower or subcrustal zone of melt accumulation. Our new observations also imply that some of the missing magma supplied to the $\sim 60-\mathrm{km}$-long September 2005 dike was sourced from the center of the Dabbahu segment, and that total deformation accrued from the intrusion of more than one discrete dike.

The inferred dike source is below the alongaxis topographic high created by the summit of the Ado'Ale Volcanic Complex. This suggests that the magma plumbing system that focuses magma beneath the center of the Dabbahu segment has maintained positional stability for at least as long as the age of the Ado'Ale Volcanic Complex, estimated as between 0.3 and $1.5 \mathrm{Ma}$ (Lahitte et al., 2003). Active dike intrusion in Afar is currently focused solely within the Dabbahu segment, showing that the melt supply beneath the middle of the rift segment that drives deformation is spatially and temporally distinct from adjacent rift segments. This also implies that the magma source beneath each rift segment only contains sufficient partial melt to supply dikes on an episodic basis. In the Ethiopian rift, a system less evolved than the subaerial Red Sea rift, structural and geophysical data show discrete, narrow, $\sim 60-\mathrm{km}$-long rift segments highly intruded by mafic dikes (Keir et al., 2006). This, coupled with episodic historical fissuring and 
effusive basaltic eruptions, suggests that episodic magma-assisted rifting, as observed in the Red Sea rift, initiates during the early stages of continental breakup.

In Afar, there are clear similarities in the spatial and temporal characteristics of melt supply with patterns observed at slow-spreading mid-ocean ridges, where the regular along-axis segmentation is thought to be produced by a segmented magma supply in passively upwelling mantle that feeds episodic crustal dike injection (e.g., Whitehead et al., 1984). Gravity data, as well as controlled source seismic data from the Mid-Atlantic ridge, show that melt is focused in lower crust beneath the center of rift segments, where cooling and crystallization of associated crustal melt lenses accretes relatively thick crust beneath along-axis bathymetric highs (e.g., Lin et al., 1990; Tolstoy et al., 1993; Singh et al., 2006). These short-lived crustal melt bodies episodically feed lateral propagation of basaltic dikes over tens of kilometers that accrete relatively thinner crust beneath axial grabens toward segment ends (e.g., Smith and Cann, 1999).

\section{CONCLUSION}

Our observations of deformation in the Dabbahu segment show that injection of multiple basaltic dikes along the axis of the rift accommodates the majority of strain during episodes of rapid rift opening. Magma is sourced directly to the center of the rift segment from reservoirs in the middle to lower crust or upper mantle and delivered into the upper $10 \mathrm{~km}$ during lateral dike injection, inducing seismicity and associated fault growth. Observations show the segmented magma supply responsible for the second-order along-axis segmentation of oceanic rifts develops prior to continental breakup, and it is maintained by episodes of basaltic dike intrusion.

\section{ACKNOWLEDGMENTS}

Support and funding from Addis Ababa University, the Ethiopian Air Force, the Afar State Government, and SEIS-UK (the seismic node of the Natural Environment Research Council [NERC] funded Geophysical Equipment Facility) is appreciated. Supported by NERC Urgency grant NE/D008611/1 to Ebinger and Wright, National Science Foundation grants EAR-0635822 and EAR-0613651 to Calais, and a NERC fellowship to Keir.

\section{REFERENCES CITED}

Abdallah, A., Courtillot, V., Kasser, M., Le Dain, A.Y., Lépine, J.C., Robineau, B., Ruegg, J.C., Tapponnier, P., and Tarantola, A., 1979, Relevance of Afar seismicity and volcanism to the mechanics of accreting plate boundaries: Nature, v. 282, p. 17-23, doi: 10.1038/282017a0. Ayele, A., Jacques, E., Kassim, M., Kidane, T., Omar, A., Tait, S., Nercessian, A., de Chabalier, J.-B., and King, G., 2007, The volcano-seismic crisis in Afar, Ethiopia, starting September 2005: Earth and Planetary Science Letters, v. 48 , p. $70-79$.

Barrat, J.A., Joron, J.L., Taylor, R.N., Fourcade, S., Nesbitt, R.W., and Jahn, B.M., 2003, Geo- chemistry of basalts from Manda Hararo, Ethiopia: LREE-depleted basalts in central Afar: Lithos, v. 69, p. 1-13, doi: 10.1016/S00244937(03)00044-6.

Björnsson, A., Saemundsson, K., Einarsson, P., Tryggvason, E., and Gronvald, K., 1977, Current rifting episode in north Iceland: Nature, v. 266, p. 318-323, doi: 10.1038/266318a0.

Buck, W.R., 2004, Consequences of asthenospheric variability on continental rifting, in Karner, G.D., et al., eds., Rheology and deformation of the lithosphere at continental margins: New York, Columbia University Press, p. 1-30.

Buck, W.R., Einarsson, P., and Brandsdottir, B., 2006, Tectonic stress and magma chamber size as controls on dyke propagation: Constraints from the 1975-1984 Krafla rifting episode: Geophysical Journal International, v. 111, B12404, doi: 10.1029/2005JB003879.

Calais, E., Lewi, E., Wright, T., Hamling, I., Buck, R., Ayele, A., Yirgu, G., and Ebinger, C., 2006, Postdiking deformation following the September 2005 Afar tectono-magmatic event [abs.]: Eos (Transactions, American Geophysical Union), v. 87, Fall Meeting Supplement.

Delaney, J.R., Kelley, D.S., Lilley, M.D., Butterfield, D.A., Baross, J.A., Wilcock, W.S.D., Embley, R.W., and Summit, M., 1998, The quantum event of oceanic crustal accretion: Impacts of diking at mid-ocean ridges: Science, v. 281, p. 222-230, doi: 10.1126/science.281.5374.222.

Ebinger, C.J., Keir, D., Ayele, A., Calais, E., Wright, T.J., Belachew, M., Hammond, J.O.S., Campbell, M.E., and Buck, W.R., 2008, Capturing magma intrusion and faulting process during continental rupture: Seismicity of the Dabbahu (Afar) rift: Geophysical Journal International, v. 174, p. 1138-1152, doi: 10.111/j.1365-246X. 2008.03877.x

Einarsson, P., and Brandsdóttir, B., 1980, Seismological evidence for lateral magma intrusion during the July 1978 deflation of the Krafla volcano in NE-Iceland: Journal of Geophysical Research, v. 47, p. 160-165.

Fialko, Y.A., and Rubin, A.M., 1998, Thermodynamics of lateral dike propagation: Implications for crustal accretion at slow-spreading mid-ocean ridges: Journal of Geophysical Research, v. 103 , p. $2501-2514$.

Hayward, N.J., and Ebinger, C.J., 1996, Variations in the along-axis segmentation of the Afar rift system: Tectonics, v. 15 , p. 244-257, doi: 10.1029/95TC02292.

Hofmann, C., Courtillot, V., Féraud, G., Rochette, P., Yirgu, G., Ketefo, E., and Pik, R., 1997, Timing of the Ethiopian flood basalt event and implications for plume birth and global change: Nature, v. 389, p. 838-841, doi: 10.1038/39853.

Keir, D., Ebinger, C.J., Stuart, G.W., Daly, E., and Ayele, A., 2006, Strain accommodation by magmatism and faulting as rifting proceeds to breakup: Seismicity of the northern Ethiopian rift: Journal of Geophysical Research, v. 111, B05314, doi: 10.1029/2005JB003748.

Lahitte, P., Gillot, P.-Y., Kidane, T., Courtillot, V., and Bekele, A., 2003, New age constraints on the timing of volcanism in central Afar, in the presence of propagating rifts: Journal of Geophysical Research, v. 108, no. B2, 2123, doi: 10.1029/2001JB001689.

Lin, J., Purdy, G.M., Schouten, H., Sempéré, J.-C., and Zervas, C., 1990, Evidence from gravity data for focused magmatic accretion along the Mid-Atlantic Ridge: Nature, v. 344, p. 627-632.

Lister, J.R., and Kerr, R.C., 1991, Fluid-mechanical models of crack propagation and their appli- cation to magma transport in dykes: Journal of Geophysical Research, v. 96, p. 10,04910,077 .

Makris, J., and Ginzburg, A., 1987, Afar Depression: Transition between continental rifting and seafloor spreading: Tectonophysics, v. 141, p. 199214, doi: 10.1016/0040-1951(87)90186-7.

Manighetti, I., Tapponnier, P., Gillot, P.-Y., Jacques, E., Courtillot, V., Armijo, R., Ruegg, J.C., and King, G., 1998, Propagation of rifting along the Arabia-Somalia plate boundary: Into Afar: Journal of Geophysical Research, v. 103, p. 4947-4974, doi: 10.1029/97JB02758.

Montelli, R., Nolet, G., Dahlen, F., Masters, G., Engdahl, E., and Hung, S.-H., 2004, Finitefrequency tomography reveals a variety of plumes in the mantle: Science, v. 303, p. 338343, doi: 10.1126/science. 1092485 .

Rivalta, E., and Segall, P., 2008, Magma compressibility and the missing source for some dike intrusions: Geophysical Research Letters, v. 35, L04306, doi: 10.1029/2007GL032521.

Roman, D.C., and Cashman, K.V., 2006, The origin of volcano-tectonic earthquake swarms: Geology, v. 34, p. 457-460, doi: 10.1130/ G22269.1.

Rowland, J.V., Baker, E., Ebinger, C.J., Keir, D., Kidane, T., Biggs, J., Hayward, N., and Wright, T.J., 2007, Fault growth at a nascent slowspreading ridge: 2005 Dabbahu rifting episode, Afar: Geophysical Journal International, v. 171 , p. $1226-1246$, doi: $10.1111 /$ j.1365246X.2007.03584.x.

Rubin, A.M., and Gillard, D., 1998, Dike-induced earthquakes: Theoretical considerations: Journal of Geophysical Research, v. 103, p. 10,01710,030, doi: 10.1029/97JB03514

Singh, S.C., Crawford, W.C., Carton, H., Seher, T., Combier, V., Cannat, M., Canales, J.P., Düsünür, D., Escartin, J., and Miranda, J.M., 2006, Discovery of a magma chamber and faults beneath a Mid-Atlantic hydrothermal field: Nature, v. 442, p. 1029-1032, doi: 10.1038/nature05105.

Smith, D.K., and Cann, J.R., 1999, Constructing the upper crust of the Mid-Atlantic Ridge; a reinterpretation based on the Puna Ridge, Kilauea volcano: Journal of Geophysical Research, v. 104, p. 25,379-25,399.

Tolstoy, M., Harding, A.J., and Orcutt, J.A., 1993, Crustal thickness on the Mid-Atlantic Ridge: Bull's-eye gravity anomalies and focused accretion: Science, v. 262 , p. $726-729$, doi: 10.1126/science.262.5134.726.

Tolstoy, M., and 14 others, 2006, A sea-floor spreading event captured by seismometers: Science, v. 314 , p. 1920-1922, doi: 10.1126/science. 1133950.

Vigny, C., Huchon, P., Ruegg, J.-C., Khanbari, K., and Asfaw, L.M., 2006, Confirmation of Arabia slow motion by new GPS data in Yemen: Journal of Geophysical Research, v. 111, B02402, doi: 10.1029/2004JB003229.

Whitehead, J., Dick, J.H.B., and Schouten, H., 1984, A mechanism for magmatic accretion under spreading centres: Nature, v. 312, p. 146-148, doi: $10.1038 / 312146 \mathrm{a} 0$

Wright, T.J., Ebinger, C., Biggs, J., Ayele, A., Yirgu G., Keir, D., and Stork, A., 2006, Magmamaintained rift segmentation at continental rupture in the 2005 Afar dyking episode: Nature, v. 442, p. 291-294, doi: 10.1038/nature04978.

Manuscript received 14 May 2008

Revised manuscript received 18 September 2008

Manuscript accepted 19 September 2008

Printed in USA 